\title{
Defoliation height and potassium fertilization of Mulato II grass
}

\section{Altura de desfolha e adubação potássica do capim Mulato II}

\author{
Carlos Eduardo Avelino Cabral ${ }^{1 *}$; Lilian Chambó Rondena Pesqueira-Silva ${ }^{2}$; \\ Lívia Vieira de Barros ${ }^{3}$; Arthur Behling Neto ${ }^{4}$; Joadil Gonçalves de Abreu; \\ Carla Heloisa Avelino Cabral ${ }^{1}$; Felipe Gomes da Silva ${ }^{3}$; Rosemary Lais Galati ${ }^{3}$; \\ Ana Maria Ribeiro Fiori ${ }^{5}$; Carlos Alberto Silva Junior ${ }^{6}$
}

\begin{abstract}
A pot trial in greenhouse conditions was carried out to identify at which defoliation height Mulato II grass (Urochloa hibrida cv. Mulato II) should be managed and to determine whether potassium fertilization is necessary in soil with high potassium content. The experiment was carried out in a greenhouse in a randomized block design with six treatments and five replications. Treatments consisted of a $3 \times 2$ factorial arrangement, with three defoliation heights $(50,65$, and $80 \mathrm{~cm})$ and with or without potassium maintenance fertilization. The production characteristics and chemical composition of the forage plant were evaluated. There was no interaction effect between defoliation height and fertilization with or without potassium on any of the analyzed variables, except for mineral content in Mulato II grass. The tillers and leaves number, shoot dry matter, leaf + sheath, root system, and residue were influenced by defoliation heights and potassium fertilization, except for the leaf blades and root dry matter, leaf blade/ stem+sheath ratio, and leaves number, which were not influenced by potassium fertilization. Higher shoot dry matter was observed at the heights of 65 and $80 \mathrm{~cm}$; however, comparing these two heights, leaf + sheath dry matter was lower at $65 \mathrm{~cm}$. Regarding the grass's chemical composition, there was an increase in neutral and acid detergent fiber and indigestible neutral detergent fiber contents as the defoliation height increased, which resulted in lower production of potentially digestible dry matter, which can compromise the potential use of the forage by animals. Among evaluated treatments, Mulato II grass defoliation is recommended for a maximum height of $65 \mathrm{~cm}$. Potassium fertilization increases the yield and the potentially digestible dry matter content of Mulato II grass, even when cultivated in soil with high potassium content.
\end{abstract}

Key words: Brachiaria hibrida. Maintenance fertilization. Pre-grazing height.

\section{Resumo}

Objetivou-se identificar em qual altura de desfolha deve ser manejado o capim Mulato II (Urochloa hibrida cv. Mulato II), bem como verificar se há necessidade de adubação potássica em solo com elevado

1 Profs. Drs., Universidade Federal de Mato Grosso, UFMT, Rondonópolis MT, Brasil. E-mail: carlos.eduardocabral@hotmail. com; cabralcha@hotmail.com

2 Discente, Curso de Doutorado, Programa de Pós-Graduação em Ciência Animal, UFMT, Cuiabá, MT, Brasil. E-mail: lilianrondena@hotmail.com

3 Profs. Drs., UFMT, Cuiabá, MT, Brasil. E-mail: liviavieiradebarros@gmail.com; joadil@terra.com.br; felipe.melhoramento@ gmail.com; galatirosemarylais@gmail.com

4 Prof. Dr., UFMT, Sinop, MT, Brasil. E-mail: arthur_behling@hotmail.com

5 Discente, Curso de Graduação em Zootecnia, UFMT̄, Cuiabá, MT, Brasil. E-mail: anamariafiori@hotmail.com

6 Discente, Curso de Graduação em Agronomia, UFMT, Cuiabá, MT, Brasil. E-mail: carlos.alberto-sj@hotmail.com

* Author for correspondence

Received: Oct. 28, 2016 Approved: May 15, 2017 
teor de potássio. O experimento foi realizado em casa de vegetação, em delineamento experimental em blocos casualizados, com seis tratamentos e cinco repetições, em esquema fatorial $3 \times 2$. Os tratamentos consistiram em três alturas de desfolha $(50,65$ e $80 \mathrm{~cm})$, sendo cada altura de desfolha avaliada com ou sem adubação de manutenção com potássio. Foram avaliadas as características produtivas e a composição bromatológica da forrageira. As alturas de corte e adubação ou não com potássio não apresentaram efeito de interação para nenhuma das variáveis analisadas, exceto para teor de minerais no capim Mulato II. O perfilhamento, massa seca da parte aérea, colmo + bainha, número de folhas e massa seca de raiz e resíduos foram influenciadas pelas alturas de corte e adubação com potássio, com exceção a massa de lâminas foliares, raiz, relação lâmina foliar/colmo+bainha e número de folhas, que não foram influenciadas pela adubação potássica. Observou-se maior massa seca de parte aérea nas alturas de 65 e $80 \mathrm{~cm}$, contudo, comparando estas duas alturas, houve menor massa seca de colmo+bainha na altura de $65 \mathrm{~cm}$. Em relação à composição bromatológica do capim Mulato II, houve incremento nos teores de fibra em detergente neutro, fibra em detergente ácido e fibra em detergente neutro indigestível com o acréscimo da altura de desfolha, o que resultou em menor produção de matéria seca potencialmente digestível e consequentemente pode comprometer o potencial de utilização da forrageira pelo animal. Dentre as alturas avaliadas, recomenda-se que o capim Mulato II seja cortado, no máximo, a $65 \mathrm{~cm}$ de altura. A adubação potássica aumenta a produção e a matéria seca potencialmente digestível do capim Mulato II mesmo cultivado em solo com elevado teor de potássio.

Palavras-chave: Adubação de manutenção. Altura pré-pastejo. Brachiaria hibrida.

\section{Introduction}

In tropical regions, pastures have significant importance, since they provide the main feed for ruminants, allowing competitiveness in meat and milk production. Due to this importance, forage breeding programs have contributed to the development of cultivars aiming for satisfactory yield in soils of lower fertility, less susceptibility to climatic adversities, and attacks of pests such as spittlebugs.

The developed research gave rise to some hybrids, such as Mulato II grass (Urochloa hibrida cv. Mulato II - CIAT 36087), developed by the Tropical Forages Project of the International Center for Tropical Agriculture (CIAT) in Colombia from the crossing of three Urochloa species (U. brizantha $\mathrm{x} U$. decumbens $\mathrm{x} U$. ruziziensis) (ARGEL et al., 2007). Even though Mulato II grass has been on the market for some time, there is a shortage of studies concerning its management, considering that forages with different growth habits and fertility requirements have been used. Regarding the hybrids with few studies, it is necessary to carry out research to evaluate the factors related to management, such as canopy height monitoring and control, since it influences directly the chemical composition and, consequently, the nutritive value of the forage, because a lower maintenance height allows a higher leaf blade:stem+sheath ratio and better forage nutritional value (MARANHÃO et al., 2010).

Besides the lack of canopy structure control, cattle producers in Brazil do not usually periodically fertilize the pasture, and those that do, prioritize nitrogen fertilization, to the detriment of other nutrients. Nitrogen $(\mathrm{N})$ and potassium $(\mathrm{K})$ are the nutrients most extracted by forage grasses (COSTA et al., 2008a, 2010). In cases with high nitrogen fertilization, potassium extraction can be higher than nitrogen (COSTA et al., 2010; BATISTA et al., 2011), which demonstrates the importance of potassium fertilization in intensive systems.

Although potassium does not present a structural function, its main importance is associated to enzymatic activation, the opening and closing of the stomata, and the improvement of resistance against water stress, resulting in better regulation of physiological processes (TAIZ; ZEIGER, 2012). Therefore, to obtain higher yield, adequate doses of $\mathrm{K}$ should be provided, especially in systems with higher fertilization intensification, since when 
there is fertilization with high nitrogen doses, the absorption and export of $\mathrm{K}$ are high (PRIMAVESI et al., 2006; COSTA et al., 2010). The goal of the present study was to identify the defoliation height of Mulato II grass (Urochloa hibrida cv. Mulato II) management, as well as to verify if potassium fertilization is required in soil with high potassium content.

\section{Material and Methods}

The experiment was carried out in a greenhouse at the Federal University of Mato Grosso, Cuiaba University Campus, over 135 days. The experimental design was a randomized block design with five replications. Treatments consisted of a 3 x 2 factorial design, with three cutting heights (50, 65 , and $80 \mathrm{~cm}$ ) and two maintenance fertilizations (with and without potassium). Each experimental unit consisted of a pot with a capacity of $4.0 \mathrm{dm}^{3}$ containing three plants. The soil used was Oxisol, which was collected at the 0 to $20 \mathrm{~cm}$ layer (Table 1) and then sieved and transferred to the pot.

Table 1. Granulometric and chemical characterization of the soil in the $0-20 \mathrm{~cm}$ layer.

\begin{tabular}{|c|c|c|c|c|c|c|c|c|c|c|c|}
\hline $\mathrm{pH}$ & $\mathrm{P}$ & K & $\mathrm{Ca}$ & $\mathrm{Mg}$ & Al & $\mathrm{H}$ & CTC & V & Areia & Silte & Argila \\
\hline $\mathrm{H}_{2} \mathrm{O}$ & \multicolumn{2}{|c|}{$\mathrm{mg} \mathrm{dm}^{-3}$} & \multicolumn{5}{|c|}{$\mathrm{cmol}_{\mathrm{c}} \mathrm{dm}^{-3}$} & $\%$ & \multicolumn{3}{|c|}{$\mathrm{g} \mathrm{kg}^{-1}$} \\
\hline 6.5 & 22.0 & 152.1 & 7.4 & 2.0 & 0.0 & 1.4 & 11.19 & 87 & 800 & 120 & 80 \\
\hline
\end{tabular}

The soil was maintained with maximum water retention capacity, determined according to Cabral et al. (2016). Phosphate fertilization $\left(\mathrm{P}_{2} \mathrm{O}_{5}\right)$ was performed together with the sowing in the amount of $300 \mathrm{mg} \mathrm{dm}^{-3}$ using superphosphate $\left(20 \% \mathrm{P}_{2} \mathrm{O}_{5}\right)$. The sowing was performed with 15 seeds per pot, and the plants were thinned to three plants per pot 10 days after emergence. After the thinning, nitrogen (N) and potassium $\left(\mathrm{K}_{2} \mathrm{O}\right)$ fertilization was carried out at the doses of 50 and $25 \mathrm{mg} \mathrm{dm}^{-3}$, respectively. The fertilizers used were ammonium sulphate $(21 \%$ $\mathrm{N})$ and potassium chloride $\left(58 \% \mathrm{~K}_{2} \mathrm{O}\right)$.

Uniformization cutting was performed 42 days after sowing, considering a residue height of $15 \mathrm{~cm}$. Subsequently, maintenance fertilization was carried out with nitrogen at a dose of $200 \mathrm{mg} \mathrm{dm}^{-3}$. A dose of $70 \mathrm{mg} \mathrm{dm}{ }^{-3}$ of $\mathrm{K}_{2} \mathrm{O}$ was applied to the maintenance treatments with potassium. The same fertilizers as the implantation fertilization were used.

The height of the plants was measured daily with a graduated ruler, and when the plants reached the height of the respective treatment, the tillers and leaves were counted, and then the plants were cut considering the mentioned residue height $(15 \mathrm{~cm})$. Four cuts were made for the height of $50 \mathrm{~cm}$, three cuts for $65 \mathrm{~cm}$, and two cuts for $80 \mathrm{~cm}$. The tillering was calculated by the difference between the initial and final number of tillers.

After the cuts, the morphological composition of the grass was determined, separating leaf blades and stem + sheath. These fractions were packed in paper bags and dried in an air circulation oven at $55 \pm 5^{\circ} \mathrm{C}$ for 72 hours. At the last cut, the mass of the root and the residue were collected, which were also submitted to drying in an air circulation oven. After each cut, a maintenance fertilization was performed at the doses and with the fertilizers already described.

The dried samples were ground in a Wiley mill until they could pass through a 20 mesh steel sieve. Pre-dried samples were analyzed for the chemical composition of the forage. The contents of dry matter (DM), crude protein (CP), and mineral matter (MM) were estimated according to AOAC (1995); 
neutral detergent fiber (NDF) according to Mertens (2002); and acid detergent fiber (FDA) according to van Soest and Robertson (1985). The indigestible neutral detergent fiber (iNDF) was estimated by the methodology described by Valente et al. (2011). The potentially digestible dry matter (PDDM) was estimated according to the equation proposed by Paulino et al. (2008). Data were subjected to analysis of variance, and the means were compared by the Tukey test, adopting a probability level of $5 \%$.

\section{Results and Discussion}

Cutting heights and fertilization or not with potassium presented no interaction effect for any of the analyzed variables, except for mineral content in Mulato II grass. The number of tillers and leaves, the shoot dry mass, the stem+sheath, the root system, and residues were influenced by the cutting heights and potassium fertilization, except for the shoot and root dry mass and the number of leaves, which were not influenced by potassium fertilization (Table 2 ).

Table 2. Number of tillers, leaves, dry mass of root, and residue of Mulato II grass submitted to cutting heights and potassium fertilization.

\begin{tabular}{lccccc}
\hline Variation source & Height & Tiller & Leaf & Root & Residue \\
\hline Height $(\mathrm{cm})$ & $(\mathrm{cm})$ & (number pot-1) & (number pot-1) & g pot $^{-1}$ \\
\hline 50 & $52.16 \mathrm{c}$ & $9.0 \mathrm{a}$ & $243.70 \mathrm{a}$ & $14.46 \mathrm{~b}$ & $7.99 \mathrm{~b}$ \\
65 & $64.73 \mathrm{~b}$ & $8.3 \mathrm{a}$ & $221.66 \mathrm{ab}$ & $39.87 \mathrm{a}$ & $12.38 \mathrm{a}$ \\
80 & $79.90 \mathrm{a}$ & $2.3 \mathrm{~b}$ & $195.30 \mathrm{~b}$ & $65.19 \mathrm{a}$ & $12.13 \mathrm{a}$ \\
\hline Fertilization & & & & & \\
\hline Without K & - & $4.13 \mathrm{~b}$ & $208.86 \mathrm{a}$ & $34.14 \mathrm{a}$ & $9.97 \mathrm{~b}$ \\
With K & - & $8.92 \mathrm{a}$ & $232.28 \mathrm{a}$ & $45.41 \mathrm{a}$ & $11.95 \mathrm{a}$ \\
CV (\%) & 3.49 & 61.05 & 11.41 & 55.21 & 14.71 \\
\hline
\end{tabular}

Means followed by the same small letter in the column do not differ among themselves by the Tukey test $(\mathrm{p}>0.05)$.

Higher numbers of tillers and leaves were obtained in Mulato II grass cut at heights of 50 and $65 \mathrm{~cm}$ (Table 2). In pastures with lower heights, there is a larger number of tillers of smaller size, because at low canopy height there is greater luminosity at the base of the plants, and, more specifically, the $\mathrm{red} / \mathrm{red}$ distant ratio increases, which stimulates tillering in grasses (EVERS et al., 2011). This response is typical of plant adaptation to grazing and for competition for light within the community (SBRISSIA; DA SILVA, 2008).

As mentioned above, light is the external factor that influences tillering, which may have contributed to the lower number of tillers at the highest height $(80 \mathrm{~cm})$. Additionally, it is possible that the cut of the plants at $15 \mathrm{~cm}$ (residue) eliminated the apical meristem of the plants kept at $80 \mathrm{~cm}$, resulting in the death of the tiller, which was evidenced by Lopes et al. (2011). The regeneration capacity of leaf tissue is one of the main reasons tropical forages persist after cutting, due to the emission of leaves from the apical meristem, which remain below the cutting and/or grazing height.

The higher total shoot dry mass in Mulato II grass was obtained when this grass was cut at heights of 65 and $80 \mathrm{~cm}$ (Table 3); however, there was a lower dry mass of stem+sheath at $65 \mathrm{~cm}$ height, which can be observed by the higher leaf blade/stem+sheath ratio for the height of $65 \mathrm{~cm}$ in relation to $80 \mathrm{~cm}$. The higher proportion of leaf blades in forages defoliated at $65 \mathrm{~cm}$ justifies the higher nutrient content and PDDM and the lower indigestible fiber content (Table 4). The leaf blade is the most digestible and nutritive fraction of the 
forage for animal feeding (SOARES et al., 2009), so it should be prioritized in grazing management. Thus, with greater heights there is lower CP content and a higher amount of fiber, even indigestible fiber. This reduction in nutrient value related to the increase in forage heights is clear in the literature (SANTOS et al., 2010, 2012).

Table 3. Shoot dry mass per cut (SDM/cut), total (SDM), leaf blades (DMLB), stem+sheath (SSDM), and leaf blade/ stem+sheath (LB/SS) ratio of Mulato II grass submitted to cutting heights and potassium fertilization.

\begin{tabular}{|c|c|c|c|c|c|}
\hline \multirow{2}{*}{ Variation source } & SDM/cut & SDM & LBDM & SSDM & LB/SS \\
\hline & \multicolumn{4}{|c|}{$\mathrm{g} \mathrm{pot}^{-1}$} & - \\
\hline \multicolumn{6}{|l|}{ Cutting height } \\
\hline 50 & $7.68 \mathrm{c}$ & $30.72 \mathrm{c}$ & $22.73 \mathrm{~b}$ & $8.01 \mathrm{c}$ & $2.85 \mathrm{a}$ \\
\hline 65 & $15.28 \mathrm{~b}$ & $45.84 \mathrm{~b}$ & 31.84 a & $13.99 \mathrm{~b}$ & $2.31 \mathrm{~b}$ \\
\hline 80 & $26.36 \mathrm{a}$ & $52.72 \mathrm{a}$ & $30.30 \mathrm{a}$ & $22.32 \mathrm{a}$ & $1.38 \mathrm{c}$ \\
\hline \multicolumn{6}{|l|}{ Fertilization } \\
\hline Without K & $15.55 \mathrm{~b}$ & $40.63 \mathrm{~b}$ & $27.02 \mathrm{a}$ & $13.60 \mathrm{~b}$ & $2.24 \mathrm{a}$ \\
\hline With K & $18.02 \mathrm{a}$ & $46.64 \mathrm{a}$ & $30.12 \mathrm{a}$ & $16.52 \mathrm{a}$ & $2.07 \mathrm{a}$ \\
\hline CV (\%) & 15.47 & 16.77 & 15.14 & 19.75 & 14.25 \\
\hline
\end{tabular}

Means followed by the same small letter in the column do not differ among themselves by the Tukey test $(p>0.05)$.

Table 4. Chemical composition of Mulato II grass submitted to cutting heights and potassium fertilization.

\begin{tabular}{lccccc}
\hline Variation source & NDF & ADF & iNDF & PDDM & CP \\
\hline Cutting height & \multicolumn{5}{c}{$\%$} \\
\hline 50 & $55.58 \mathrm{c}$ & $38.83 \mathrm{~b}$ & $18.47 \mathrm{c}$ & $80.64 \mathrm{a}$ & $13.96 \mathrm{a}$ \\
65 & $59.52 \mathrm{~b}$ & $39.34 \mathrm{~b}$ & $20.67 \mathrm{~b}$ & $78.51 \mathrm{~b}$ & $10.00 \mathrm{~b}$ \\
80 & $65.60 \mathrm{a}$ & $41.43 \mathrm{a}$ & $23.01 \mathrm{a}$ & $76.30 \mathrm{c}$ & $5.83 \mathrm{c}$ \\
\hline Fertilization & & & & \\
\hline Without K & $60.51 \mathrm{a}$ & $39.97 \mathrm{a}$ & $21.41 \mathrm{a}$ & $77.80 \mathrm{~b}$ & $10.61 \mathrm{a}$ \\
With K & $59.95 \mathrm{a}$ & $39.76 \mathrm{a}$ & $20.02 \mathrm{~b}$ & $79.17 \mathrm{a}$ & $9.25 \mathrm{~b}$ \\
CV (\%) & 3.72 & 2.59 & 5.84 & 1.53 & 8.52 \\
\hline
\end{tabular}

Means followed by the same small letter in the column do not differ among themselves by the Tukey test ( $p>0.05)$. NDF: neutral detergent fiber; ADF: acid detergent fiber; iNDF: indigestible neutral detergent fiber; PDDM: potentially digestible dry matter; CP: crude protein.

At greater height $(80 \mathrm{~cm})$ of Mulato II grass, because of the higher proportion of stem, there was a greater iNDF content due to the larger amount of indigestible tissues, such as xylem and sclerenchyma (BAUER et al., 2008; CABRAL et al., 2011). In addition, NDF, ADF, and iNDF contents in the forage increased with the increase in cutting height, whereas the levels of PDDM and CP reduced. With stem elongation, there is a reduction of the forage nutritional value, characterized by a greater fiber content, reduced protein content, and DM digestibility (CASTRO et al., 2009). Protein content lower than 8 to $11 \%$ limited the full capacity of the fibrous components' use by rumen microorganisms, resulting in rumen fill of iNDF (LAZZARINI et al., 2009), which could limit the digestion of Mulato II grass at the greatest height.

Even in soil with high potassium content (Table 1), the potassium fertilization positively affected the tillering process (Table 2), which was verified by Scaramuzza et al. (2007). Similarly, fertilization 
with potassium provided an increase in the dry mass of residue, shoot dry mass, leaf blade, and stem+ sheath (Tables 2 and 3), without affecting the root dry mass (Table 2). Regarding the fertilization, Primavesi et al. (2006) reported that potassium fertilization increases the efficiency of nitrogen use. This was verified in the present study, since the potassium content was considered adequate (VILELA et al., 2007), and, even so, a higher shoot dry mass was evidenced when the forage was fertilized with potassium (Table 3). Other authors have evaluated the effects of potassium fertilization on Urochloa brizantha, cv. Marandu at various growth stages and verified that the total DM yields presented linear increases with the increase of $\mathrm{K}$ doses, except in the initial period, indicating that the initial $\mathrm{K}$ content in the unfertilized soil was sufficient for the grass implantation and initial growth (GAMA-RODRIGUES et al., 2002). The grass not fertilized with potassium presented higher CP content (Table 4); therefore, the lower DM yield for these plants resulted in higher nitrogen accumulation in the plant, since in lower production (Table 3) a greater accumulation of nutrients is observed, which is commonly referred to as dilution and/or concentration effect.

There was an interaction effect between cutting heights and potassium fertilization for mineral content in Mulato II grass (Table 5). For each cutting height, the potassium fertilization did not influence the mineral content. On the other hand, in the presence of potassium fertilization, higher ash content of the Mulato II grass was obtained with the cutting at $50 \mathrm{~cm}$ height, whereas in the absence of potassium, greater ash contents were obtained at heights of 50 and $65 \mathrm{~cm}$. It is evident that there was a dilution effect, since at higher height $(80$ $\mathrm{cm}$ ) there was an increase in production (Table 5), which reduced the concentration of minerals. The literature explains that potassium fertilization increases the potassium content in the plant (COSTA et al., 2008b), which favors the increase in mineral content.

Table 5. Mineral matter (\%) of Mulato II grass submitted to cutting heights and potassium fertilization.

\begin{tabular}{lccc}
\hline Treatment & \multicolumn{3}{c}{ Cutting height $(\mathrm{cm})$} \\
\cline { 2 - 4 } & 50 & 65 & 80 \\
Without K & $10.05 \mathrm{Aa}$ & $9.91 \mathrm{Aa}$ & $8.90 \mathrm{Ab}$ \\
With K & $10.69 \mathrm{Aa}$ & $9.23 \mathrm{Ab}$ & $8.78 \mathrm{Ab}$ \\
\hline
\end{tabular}

Means followed by the same capital letter in the column and by small letters in the row do not differ among themselves by the Tukey test $(\mathrm{p}>0.05)$.

In summary, among evaluated heights, given the forage production and the morphological and chemical composition, it is recommended to cut or pasture Mulato II grass up to the height of $65 \mathrm{~cm}$, considering that at the height of $50 \mathrm{~cm}$ occurs higher nutritional value and lower production compared to height of $65 \mathrm{~cm}$. The increase of $\mathrm{K}$ contents in the soil, under adequate availability conditions, produces beneficial effects in terms of shoot DM accumulation, thereby increasing the supply of available forage. In addition, Mulato II grass is responsive to potassium fertilization, since, even in soils with elevated levels of $\mathrm{K}$, the forage responded to this nutrient use.

\section{Conclusions}

We recommend defoliation of Mulato II grass at the heights of 50 and $65 \mathrm{~cm}$. Potassium fertilization increases the production and PDDM of Mulato II grass, even when cultivated in soil with high potassium content. 


\section{References}

ARGEL, P. J.; MILlES, J. W.; GULIOT, J. D.; CUADRADO, H.; LASCANO, C. E. Cultivar mulato II (Brachiaria hibrida CIAT 36087): high quality forage grass, resistant to the spittlebug and adpeted to welldrained acid tropical soils. Cali: International Center for Tropical Agriculture, 2007. 21 p.

ASSOCIATION OF OFFICIAL ANALYTICAL CHEMISTS - AOAC International. Official methods of analysis. 16. ed. Washington, D.C.: AOAC, 1995.

BATISTA, K.; DUARTE, A. P.; CECCON, G.; DE MARIA, I. C.; CANTARELLA, H. Acúmulo de matéria seca e de nutrientes em forrageiras consorciadas com milho safrinha em função da adubação nitrogenada. Pesquisa Agropecuária Brasileira, Brasília, v. 46, n. 10, p. 1154-1160, 2011.

BAUER, M. O.; GOMIDE, J. A.; SILVA, E. A. M.; REGAZZI, A. J.; CHICHORRO, J. F. Características anatômicas e valor nutritivo de quatro gramíneas predominantes em pastagem natural de Viçosa, MG. Revista Brasileira de Zootecnia, Viçosa, v. 37, n. 1, p. 9-17, 2008.

CABRAL, C. E. A.; CABRAL, L. S.; BONFIM-SILVA, E. M.; CARVALHO, K. S.; KROTH, B. E.; CABRAL, C. H. A. Resposta da Brachiaria brizantha cv. Marandu a fertilizantes nitrogenados associados ao fosfato natural reativo. Comunicata Scientiae, Bom Jesus, v. 7, n. 1, p. 66-72, 2016.

CABRAL, C. H. A.; BAUER, M. O.; CABRAL, C. E. A. Influência das características anatômicas e estruturais do dossel forrageiro no consumo de ruminantes. Enciclopédia Biosfera, Goiânia, v. 7, n. 13, p. 680-693, 2011.

CASTRO, C. R. T.; PACIUllo, D. S.; GOMIDE, C. A. M.; MÜLLER, M. D.; NASCIMENTO JUNIOR, E. R. Características agronômicas, massa de forragem e valor nutritivo de Brachiaria decumbens em sistema silvipastoril. Pesquisa Florestal Brasileira, Colombo, v. 29, n. 60, p. 19-25, 2009.

COSTA, K. A. P.; ARAUJO, J. L.; FAQUIN, V.; OLIVEIRA, I. P.; FIGUEIREDO, F. C.; GOMES, K. W. Extração de macronutrientes pela fitomassa do capimxaraés "xaraés" em função de doses de nitrogênio e potássio. Ciência Rural, Santa Maria, v. 38, n. 4, p. $1162-$ 1166, 2008a.

COSTA, K. A. P.; OLIVEIRA, I. P.; FAQUIN, V.; FIGUEIREDO, F. C.; RODRIGUES, C. R.; NASCIMENTO, P. P. Adubação nitrogenada e potássica na concentração de nutrientes do capim-Xaraés. Ciência Animal Brasileira, Goiânia, v. 9, n. 1, p. 86-92, 2008 b.
COSTA, K. A. P.; OLIVEIRA, I. P.; SEVERIANO, E. C.; SAMPAIO, F. M. T.; CARRIJO, M. S.; RODRIGUES, C. R. Extração de nutrientes pela fitomassa de cultivares de Brachiaria brizantha sob doses de nitrogênio. Ciência Animal Brasileira, Goiânia, v. 11, n. 2, p. 307-311, 2010.

EVERS, J. B.; KROL, A. R.; VOS, J.; STRUIK, P. C. Understanding shoot branching by modelling form and function. Trends in Plant Science, Cambridge, v. 16, n. 9, p. 464-467, 2011.

GAMA-RODRIGUES, A. C.; ROSSIELlO, R. O. P.; CARVALHO, C. A. B.; ADESI, B. Produção e partição de matéria seca em Brachiaria brizantha em resposta à fertilização potássica e às datas de corte. Agronomia, Rio de Janeiro, v. 36, n. 1-2, p. 23-28, 2002.

LAZZARINI, I.; DETMANN, E.; SAMPAIO, C. B.; PAULINO, M. F.; VALADARES FILHO, S. C.; SOUZA, M. A.; OLIVEIRA, F. A. Dinâmicas de trânsito e degradação da fibra em detergente neutro em bovinos alimentados com forragem tropical de baixa qualidade e compostos nitrogenados. Arquivo Brasileiro de Medicina Veterinária e Zootecnia, Belo Horizonte, v. 61, n. 3, p. 635-647, 2009.

LOPES, M. N.; CÂNDIDO, M. J. D.; POMPEU, R. C. F. F.; SILVA, R. G.; BEZERRA, F. M. L. Componentes estruturais do resíduo pós-corte em capim-massai adubado com cinco doses de nitrogênio. Revista Ciência Agronômica, Fortaleza, v. 42, n. 2, p. 518-525, 2011.

MARANHÃO, C. M. A; BONOMO, P.; PIRES, A. J. V.; COSTA, A. C. P. R.; MARTINS, G. C. F.; CARDOSO, E. O. Características produtivas do capim-braquiária submetido a intervalos de cortes e adubação nitrogenada durante três estações. Acta Scientiarum. Animal Sciences, Maringá, v. 32, n. 4, p. 375-384, 2010.

MERTENS, D. R. Gravimetric determination of amylasetreated neutral detergent fiber in feeds with refluxing in beaker or crucibles: collaborative study. Journal of AOAC International, Rockville, v. 85, n. 6, p. 1217-1240, 2002.

PAULINO, M. F.; DETMANN, E.; VALADARES FILHO, S. C. Bovinocultura funcional nos tópicos. In: SIMPÓSIO DE PRODUÇÃO DE GADO DE CORTE, 6; SIMPÓSIO INTERNACIONAL DE PRODUÇÃO DE GADO DE CORTE, 2., 2008, Viçosa, MG. Anais... Viçosa, MG: VI SIMCORTE, 2008. p. 275-305.

PRIMAVESI, A. C.; PRIMAVESI, O.; ORRÊA, L. A.; SILVA, A. G.; CANTARELLA, H. Nutrientes na fitomassa de capim-marandu em função de fontes e doses de nitrogênio. Revista Ciência e Agrotecnologia, Lavras, v. 30, n. 3, p. 562-568, 2006. 
SANTOS, M. E. R.; FONSECA, D. M.; SILVA, G. P.; PIMENTEL, R. M.; CARVALHO, V. V.; SILVA, S. P. Estrutura do pasto de capim-braquiária com variação de alturas. Revista Brasileira de Zootecnia, Viçosa, v. 39, n. 10, p. 2125-2131, 2010.

SANTOS, M. S.; OLIVEIRA, M. E.; RODRIGUES, M. M.; VELOSO FILHO, E. S.; ARAUJO NETO, J. C. Estrutura e valor nutritivo de pastos de capins Tanzânia e Marandu aos 22 e 36 dias de rebrota para ovinos. Revista Brasileira de Saúde e Produção Animal, Salvador, v. 13, n. 1, p. 35-46, 2012.

SBRISSIA, A. F.; SILVA, S. C. da. Compensação tamanho/densidade populacional de perfilhos em pastos de capim-marandu. Revista Brasileira de Zootecnia, Viçosa, v. 37, n. 1, p. 35-47, 2008.

SCARAMUZZA, W. L. M. P.; RODRIGUES, R. C.; MONTEIRO, F. A. Características produtivas e fisiológicas do capim-mombaça submetido a doses de potássio. Boletim da Indústria Animal, Nova Odessa, v. 64, n. 3, p. 213-220, 2007.
SOARES, A. B.; SARTOR, L. R.; ADAMI, P. F.; VARELLA, A. C.; FONSECA, L.; MEZZALIRA, J. C. Influência da luminosidade no comportamento de onze espécies forrageiras perenes de verão. Revista Brasileira de Zootecnia, Viçosa, v. 38, n. 3, p. 443-451, 2009.

TAIZ, L.; ZEIGER, E. Fisiologia vegetal. 5. ed. Porto Alegre: Artmed, 2012. 954 p.

VALENTE, T. N. P.; DETMANN, E.; QUEIROZ, A. C.; VALADARES FILHO, S. C.; GOMES, D. I.; FILGUEIRAS, J. F. Evaluation of rumen degradation profiles of forages using bags made from different textiles. Revista Brasileira de Zootecnia, Viçosa, v. 40, n. 11, p. 2565-2573, 2011.

VAN SOEST, P. J.; ROBERTSON, J. B. Analysis of forages and fibrous foods. Ithaca: Cornell University, 1985. $202 \mathrm{p}$.

VILELA, L.; MARTHA JUNIOR, G. B.; SOUSA, D. M. G. Adubação potássica e com micronutrientes. In: MARTHA JUNIOR, G. B.; VILELA, L.; SOUSA, D. M. G. Cerrado: uso eficiente de corretivos e fertilizantes em pastagens. Planaltina, DF: Embrapa Cerrados, 2007. p. 179-188. 